\title{
Nasopharyngeal viral load predicts hypoxemia and disease outcome in admitted COVID-19 patients
}

\author{
Amir Shlomai ${ }^{1,2+}$, Haim Ben-Zvii ${ }^{3 \dagger}$, Ahinoam Glusman Bendersky ${ }^{1,2}$, Noa Shafran ${ }^{1,2}$, Elad Goldberg ${ }^{2,4^{* \dagger}}$ and \\ Ella H. Sklan ${ }^{5+}$
}

Keywords: Viral load, SARS-CoV-2, COVID-19, Hypoxemia

\section{Introduction}

The SARS-CoV-2 pandemic imposes an unprecedented burden on hospitals treating coronavirus disease 2019 (COVID-19) patients. Thus, clinical parameters accurately predicting disease outcome are needed. Here, we identified a correlation between viral load measured around admission, lung inflammation, and disease outcome. Similarities and differences between related studies are discussed.

\section{Methods}

Viral loads of COVID-19 patients admitted to Rabin Medical Center between March 16 and July 23, 2020, were analyzed $(n=170$, females $42 \%$, age 62 (IQR $46-$ 73), hospitalization length 7.5 days (IQR 3-13)). Clinical and demographic data were collected from the patients' electronic medical records. Nasopharyngeal samples were collected and transferred to the microbiology laboratory for testing. Quantitative RT-PCR was performed using the Allplex ${ }^{\mathrm{Tx}}$ 2019-nCoV Assay (Seegene). Presented are $\mathrm{Ct}$ values of the nucleocapsid $\mathrm{N}$ gene from the first test performed for each patient. Simple linear regression of clinical parameters against

\footnotetext{
* Correspondence: eladgol310@yahoo.com

${ }^{\dagger}$ Amir Shlomai and Haim Ben Zvi contributed equally to this work.

†Elad Goldberg and Ella H. Sklan are senior authors and contributed equally to this article.

${ }^{2}$ The Sackler Faculty of Medicine, Tel Aviv University, Tel Aviv, Israel

${ }^{4}$ Department of Medicine F, Rabin Medical Center, Beilinson Hospital, Petah Tikva, Israel

Full list of author information is available at the end of the article
}

the viral load was fitted to the data to assess the association between viral and clinical parameters using GraphPad Prism. Adjusted odds ratio (OR) of mechanical ventilation and mortality were calculated for each significant variable with $95 \%$ confidence intervals (CI) using SPSS, version 26.

\section{Results}

Cycle threshold values of the first test performed for all admitted COVID-19 patients were correlated with the patients' clinical parameters. Among the parameters tested (lowest values of albumin, lymphocyte count, blood oxygen saturation (BOS) and systolic blood pressure, peak levels of lactate dehydrogenase (LDH), Creactive protein (CRP), ferritin, white blood cell count, and fever), only $\mathrm{BOS}_{\min }(R=0.07, p=0.0004)$ showed significant correlation (Fig. 1). Interestingly, patients' age was also significantly correlated with viral load (Fig. 1). Non-survivors and mechanically ventilated patients $(n=$ 21) had a significantly higher viral load (8-folds, Ct $=$ $23.43 \pm 5.38)$ compared to surviving non-intubated patients $(n=149, \mathrm{Ct}=29 \pm 5.55, t$ test $p<0.0001$, Fig. 2$)$. A multivariate analysis adjusted for age, gender, and $\mathrm{BOS}_{\text {min }}$ revealed that low viral load was independently associated with reduced risk for mechanical ventilation and mortality (OR $=0.90,95 \%$ CI $0.81-0.99, p=0.046$ ). Furthermore, BOS and patients' age were also independently associated with mechanical ventilation and death $(\mathrm{OR}=0.91,95 \%$ CI $0.84-0.98, p=0.009$ for $\mathrm{BOS}$ and $\mathrm{OR}=1.05,95 \%$ CI $1.004-1.097$ for age). 

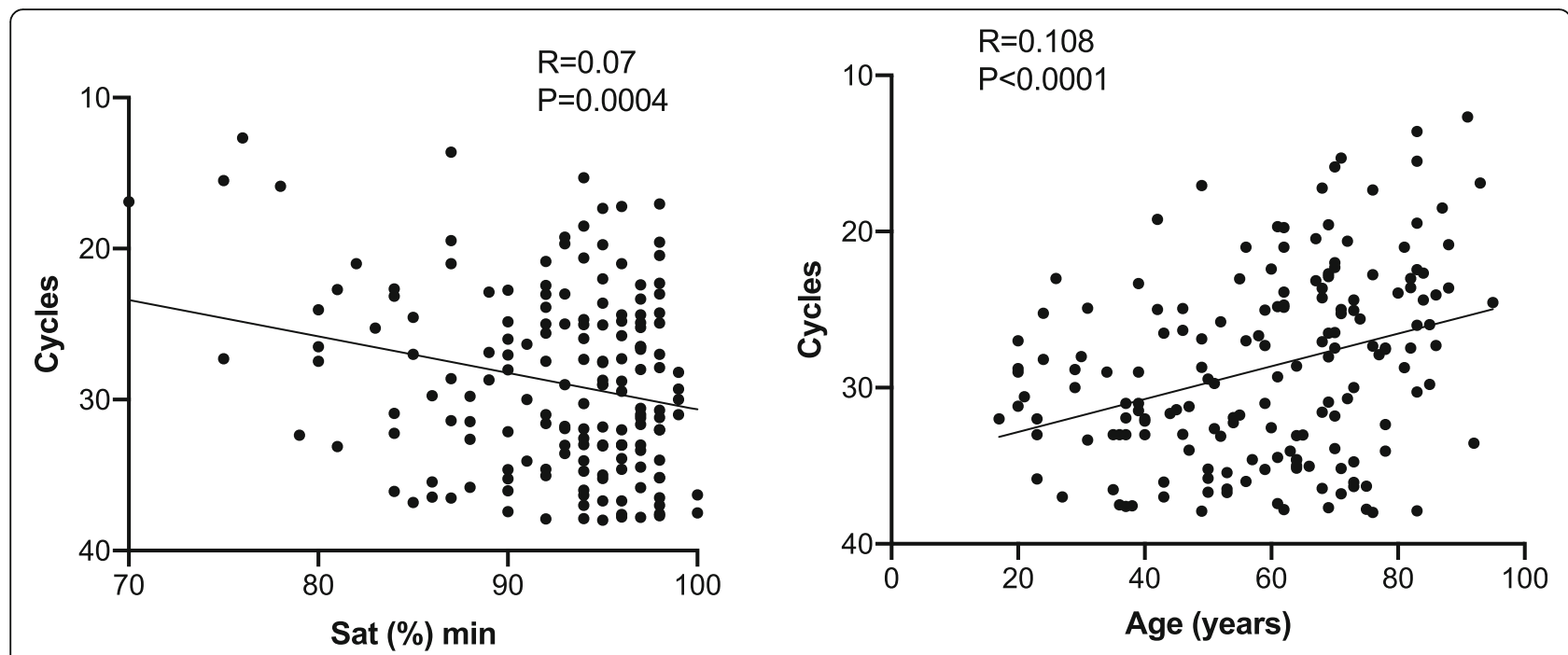

Fig. 1 Viral load is associated with minimal saturation values and age. The relationship between Ct values from the nucleocapsid gene, minimal saturation values and age $(n=170)$. Similar results were obtained with the $\mathrm{Ct}$ for the envelope gene. $(R=R$ squared, pearson's correlation test)

\section{Discussion}

Our results show a direct link between nasopharyngeal viral load and hypoxemia, as well as worse disease outcomes in admitted patients with COVID-19. Previous studies tested the association between viral load and survival. In agreement with our results, a study of 678 admitted patients in New York found that $35.0 \%$ of patients with a high viral load on admission died, compared to $6.2 \%$ of patients with low viral loads [1]. In an older age cohort $(n=48$, age 67-97) from Belgium, clinical frailty scale, LDH, and viral load predicted survival [2]. Intensive care unit (ICU) admission also positively correlated with detectable viral RNA in anal swabs [3]. In contrast, a Swiss study found no correlation between viral load and

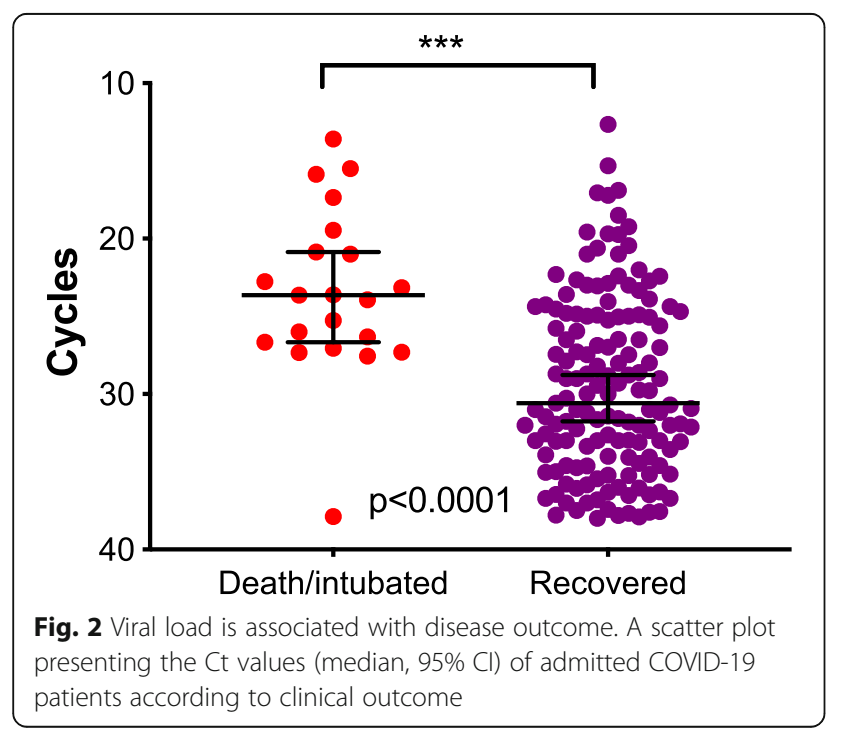

disease outcome. The study compared the viral load of patients admitted to the ICU $(n=48)$ to patients treated in a screening unit $(n=723)$ [4]. It is not clear, however, whether these patients were later admitted, intubated, or survived. A different New York study $(n=205)$ found no association between viral load and disease severity parameters. However, this study mainly compared non-hospitalized to hospitalized patients [5]. Several markers were associated with COVID-19 severity, the most accepted is IL-6 [6]. However, IL-6 is not routinely tested at admission and might reflect other inflammatory conditions. Thus, in spite of differences in test kits and procedures between different laboratories and institutions, viral load might provide a rapid screening tool for COVD-19 severity among admitted patients.

\section{Abbreviations}

SARS-CoV-2: Severe acute respiratory syndrome coronavirus 2; COVID19: Coronavirus disease 2019; IQR: Interquartile range; Ct: Cycle threshold; RTPCR: Reverse transcription polymerase chain reaction; OR: Odds ratio; Cl: Confidence interval; LDH: Lactate dehydrogenase; BOS: Blood oxygen saturation; CRP: C-reactive protein; ICU: Intensive care unit

\section{Acknowledgements}

EHS acknowledges the Milner Foundation for its support.

\section{Authors' contributions}

AS, EHS, and EG designed the work. AS, EHS, HBZ, AGB, and NS collected and analyzed the data. AS and EHS interpreted the data. EHS and AS drafted the work. All authors read and approved the final manuscript.

Funding

No funding to declare.

Availability of data and materials

The dataset supporting the conclusions of this article is available from the authors upon request. 


\section{Ethics approval and consent to participate}

This retrospective study was approved by the Rabin Medical Center Helsinki Committee (0252-20-RMC) and the Tel Aviv University Ethics Committee (0001269-3). The need for informed consent was waived due to its retrospective nature.

\section{Consent for publication}

Not applicable.

\section{Competing interests}

Not applicable.

\section{Author details}

'Department of Medicine D, Rabin Medical Center, Beilinson Hospital, Petah Tikva, Israel. ${ }^{2}$ The Sackler Faculty of Medicine, Tel Aviv University, Tel Aviv, Israel. ${ }^{3}$ Microbiology Laboratory, Rabin Medical Center, Beilinson Hospital, Petah Tikva, Israel. ${ }^{4}$ Department of Medicine F, Rabin Medical Center, Beilinson Hospital, Petah Tikva, Israel. ${ }^{5}$ Department of Clinical Microbiology and Immunology, The Sackler Faculty of Medicine, Tel Aviv University, Tel Aviv, Israel.

Received: 7 August 2020 Accepted: 12 August 2020

Published online: 01 September 2020

\section{References}

1. Magleby R, Westblade LF, Trzebucki A, Simon MS, Rajan M, Park J, Goyal P, Safford MM, Satlin MJ. Impact of SARS-CoV-2 viral load on risk of intubation and mortality among hospitalized patients with coronavirus disease 2019. Clin Infect Dis. 2020;ciaa851, https://doi.org/10.1093/cid/ciaa851.

2. De Smet R, Mellaerts B, Vandewinckele H, Lybeert P, Frans E, Ombelet S, Lemahieu W, Symons R, Ho E, Frans J, et al. Frailty and mortality in hospitalized older adults with COVID-19: retrospective observational study. J Am Med Dir Assoc. 2020;21(7):928-32 e921.

3. Lin W, Xie Z, Li Y, Li L, Wen C, Cao Y, Chen X, Ou X, Hu F, Li F, et al. Association between detectable SARS-COV-2 RNA in anal swabs and disease severity in patients with coronavirus disease 2019. J Med Virol. 2020;1-9.

4. Jacot D, Greub G, Jaton K, Opota O. Viral load of SARS-CoV-2 across patients and compared to other respiratory viruses. medRxiv. 2020:2020.2007.2015. 20154518. https://doi.org/10.1101/2020.07.15.20154518.

5. Argyropoulos KV, Serrano A, Hu J, Black M, Feng X, Shen G, Call M, Kim MJ Lytle A, Belovarac B, et al. Association of initial viral load in severe acute respiratory syndrome coronavirus 2 (SARS-CoV-2) patients with outcome and symptoms. Am J Pathol. 2020;190(9):1881-1887.

6. Liu T, Zhang J, Yang Y, Ma H, Li Z, Zhang J, Cheng J, Zhang X, Zhao Y, Xia $Z$, et al. The role of interleukin- 6 in monitoring severe case of coronavirus disease 2019. EMBO Mol Med. 2020;12(7):e12421.

\section{Publisher's Note}

Springer Nature remains neutral with regard to jurisdictional claims in published maps and institutional affiliations.

Ready to submit your research? Choose BMC and benefit from:

- fast, convenient online submission

- thorough peer review by experienced researchers in your field

- rapid publication on acceptance

- support for research data, including large and complex data types

- gold Open Access which fosters wider collaboration and increased citations

- maximum visibility for your research: over $100 \mathrm{M}$ website views per year

At $\mathrm{BMC}$, research is always in progress.

Learn more biomedcentral.com/submissions 